\title{
STRATEGI PENGEMBANGAN USAHA PENGOLAHAN IKAN ASIN JAMBAL ROTI PADA UD. SUMBER BERKAH
}

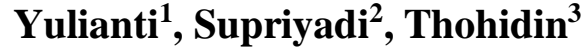 \\ ${ }^{1,2,3}$ Program Studi Agribisnis, Fakultas Pertanian, Universitas Wiralodra \\ Email: yuliantifaperta539@gmail.com ${ }^{1}$, supriyadifapertaunwir@gmail.com², tohidin@gmail.com³
}

\begin{abstract}
ABSTRAK
Penelitian ini bertujuan untuk mengetahui 1). Faktor internal ( kekuatan dan kelemahan ) ; 2). Faktor eksternal ( peluang dan ancaman ) serta 3). Rumusan strategi pengembangan usaha ikan Asin Jambal Roti di Desa Pabean Udik Kecamatan Indramayu Kabupaten Indramayu. Responden dan penelitian ditentukan secara purposive sampling, analisis data menggunakan analisis swot, metode penelitian menggunakan survei, desain penelitian survei deskriptif. Hasil penelitian ini menunjukan beberapa faktor yaitu faktor internal dan eksternal pada Usaha Ikan Asin Jambal Roti di Desa Pabean Udik yaitu faktor Strengths (Kekuatan) meliputi: Keuletan pemilik. Sumber daya manusia yang berpengalaman. Produk berkualitas. Proses pengolahan tidak rumit. Lokasi usaha yang strategis. Memiliki izin usaha dagang. Faktor Weakness (Kelemahan) meliputi: Keterbatasan modal. Kurangnya promosi produk. Teknologi masaih sederhana. Pemasaran masih dilakukan secara konvesional. Pengadministrasian masih sederhana. Faktor Opportunities (Peluang) meliputi: Dukungan dari pemerintah. Adanya perkembangan teknolgi produsi. Jangkauan masih terbuka luas. Permintaan produk tinggi. Produsen ikan asin Jambal Roti masih sedikit. Faktor Threats (Ancaman) meliputi: Duplikasi produk oleh usaha lain. Keterbatasan modal. Limbah buang proses produksi mencemari lingkungan. Harga bahan baku yang mahal.Alternative strategi pengembangan usaha pengolahan ikan asin jambal roti yang di peroleh adalah S-O yaitu kekuatan (Strenght) dan peluang (Oportuities) dimana perusahaan memiliki strategi untuk memaksimalkan kekuatan untuk memanfaatkan peluang yang ada. (1) Meningkatkan kemauan dan Memanfaatkan dukungan pemerintah daerah setempat agar usaha ikan asin jambal roti mendapatkan dukungan dari segi mempermudah perizinan dan jangkauan akses pasar yang luas dan pendanaan dengan bunga yang ringan. (2) Meningkatkan jumlah produksi dengan cara produsen mempunyai persediaan bahan baku untuk mengantisipasi permintaan produk yang tinggi dan dapat menjangkau pasar yang lebih luas.
\end{abstract}

Kata kunci - Jambal Roti, opportunities, Strenght, Weakness

\section{PENDAHULUAN}

Indonesia merupakan negara kepulauan ( Archipelagic State ) terbesar di dunia, memiliki 17.508 pulau besar dan kecil Letak geografis antara dua benua (Asia dan Afrika) serta dua samudra (Hindia dan Pasifik) yang dilalui garis katulistiwa. Tersimpan produksi perikanan tangkap $\pm 6,3$ juta ton/tahun (Suharto, 2009). Adapun potensi produksi perikanan tangkap dapat dilihatkan pada Tabel 1 di bawah ini. 
Tabel 1 Produksi Perikanan Tangkap (TON)

\begin{tabular}{ccrr}
\hline \multirow{2}{*}{ Tahun } & \multicolumn{2}{c}{ Jenis Perairan } & Umum ( Ton ) \\
\cline { 3 - 4 } & & Laut (Ton ) & 398.213 \\
2013 & & 5.707 .012 & 446.692 \\
2014 & 6.037 .654 & 473.134 \\
2015 & 6.204 .668 & 464.722 \\
Jumlah & 6.115 .469 & 1.782 .761
\end{tabular}

Provinsi Jawa Barat mempunyai 27 kabupaten/kota yang mempunyai kontribusi besar untuk meningkatkan dan pembangunan perekonomian Indonesia karena Provinsi Jawa Barat dengan letak yang sangat strategis dekat dengan Ibu Kota Indonesia, Provinsi Jawa Barat berhadapan dengan dua sisi lautan Jawa pada bagian Utara dan Samudra Hindia di bagian Selatan dengan panjang pantai sekitar $1.000 \mathrm{~km}$ (Ikbal, 2016). Kabupaten Indramayu memiliki kondisi lahan yang potensial untuk pengembangan usaha dibidang perikanan dn kelautan.. Dengan potensi yang dimiliki, maka Kabupaten Indramayu memiliki kontribusi perikanan dan kelautan terbesar di Provinsi Jawa Barat. Indramayu pada Tabel 2 di bawah ini.

Tabel 2 Jumlah Nelayan Menurut Statusnya Di Kabupaten Indramayu

\begin{tabular}{crr}
\hline \multirow{2}{*}{ Tahun } & \multicolumn{3}{c}{ Status Nelayan } & \\
\cline { 2 - 4 } \multicolumn{2}{c}{ Pemilik (RTP)* } & Buruh (RTBP)** \\
\hline Tahun 2014 & 6.057 & 34.488 \\
Tahun 2015 & 6.067 & 34.598 \\
Tahun 2016 & 6.067 & 34.598 \\
Tahun 2017 & 6.067 & 34.598 \\
Jumlah & 24.258 & 138.282 \\
\hline
\end{tabular}

Keterangan:

*RTP : : Rumah Tangga Perikanan

**RTBP $\quad$ : Rumah Tangga Buruh Perikanan Sumber : BPS Indramayu, 2018.

\section{Perumusan Masalah}

Berdasarkan keadaan yang sudah dijelaskan maka rumusan masalah dalam tugas akhir ini adalah sebagai berikut.

1. Bagaimana kekuatan, kelemahan, peluang dan ancaman dalam usaha pengolahan ikan asin Jambal Roti ?

2. Bagaimana strategi yang tepat dalam pengembangan usaha pengolahan ikan asin Jambal Roti berdasarkan analisis SWOT ?

\section{Tujuan Penelitian}

Batasan masalah yang dibuat membatasi fokus penelitian pada tugas akhir ini adalah sebagai berikut.

1. Kekuatan, kelemahan, peluang dan ancaman dalam usaha pengolahan ikan asin Jambal Roti.

2. Strategi pengembangan dalam usaha pengolahan ikan asin Jambal Roti berdasarkan analisis SWOT. 
JURNAL AGRIBISNIS

\section{Manfaat Penelitian}

Manfaat yang diharapkan setelah penelitian ini dilaksanakan adalah sebagai berikut.

1. Aspek teoritis

Hasil penelitian ini diharapkan dapat memberikan informasi dan bahan referensi bagi perkembangan perikanan khususnya pada produk hasil perikanan dan pemasaran jenis komoditi lainnya.

2. Aspek praktis

Hasil penelitian ini diharapkan dapat berguna untuk:

a. Mengetahui dan mengidentifikasi kekuatan dan kelemahan dalam pengembangan usaha pengolahan ikan asin Jambal Roti, sehingga dapat dijadikan sebagai bahan masukan yang berharga bagi instansi terkait. Baik untuk nelayan, pedagang ikan, dan pelaku usaha.

b. Mengetahui dan mengidentifikasi peluang dan ancaman untuk pengembangan usaha pengolahan ikan asin Jambal Roti, dijadikan sebagai acuan dalam menentukan strategi usaha dengan meningkatkan kualitas, kuantitas, dan kontinuitas.

c. Mengetahui solusi alternatif dalam strategi pengembangan usaha pengolahan ikan asin Jambal Roti.

\section{KAJIAN PUSTAKA DAN KERAGKA PEMIKIRAN}

\section{Kajian Pustaka}

\section{Klasifikasi Ikan Manyung}

Ikan Manyung tergolong dalam famili Ariidae, dengan nama latin Arius thalassinus. Ikan terseubt mempunyai sebutan yang berbeda-beda di setiap daerah. Di Jawa disebut sebagai ikan Manyong, Manyung Kerbi, atau Duri Utik. Lain lagi sebutan di daerah Riau yaitu disebut Duri Utek atau Duri Padi, Berbeda dengan Sulawesi Selatan yang menyebutnya dengan Barukang, sementara itu di Sumatera Selatan sisebut dengan ikan Gagak Putih, dan di Kalimatan Barat dinamakan dengan ikan Gugup (Burhanuddin et al., 1987).

Saanin (1968), ikan Manyung (Arius thalassinus) dapat diklasifikasikan sebagai berikut:
a) Kingdom : Animalia
b) Phylum : Chordata
c) Class : Pisces
d) Subclass : Teleostei
e) Ordo : Ostariophysis
f) Familii : Ariidae
g) Genus : Arius
h) Spesies : Arius thalassinus

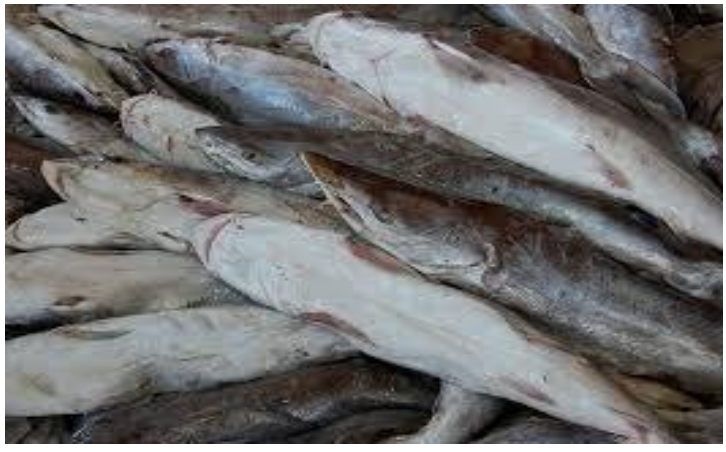

Gambar 1 Ikan Manyung 
Ikan Asin

Ikan asin adalah bahan makanan yang terbuat dari daging ikan yang diawetkan dengan menambahkan banyak garam. Dengan metode pengawetan dapat memperpanjang umur masa simpan. Ikan mengandung unsur penting yang dibutuhkan oleh tubuh manusia seperti protein yang tinggi, asam amino essensial dan struktur ikan dapat mudah dicerna oleh (Adawyah, 2007).

\section{Pengolahan Ikan Asin Jambal Roti}

Proses pengolahan ikan asin Jambal Roti ini meliputi penggaraman, fermentasi, dan pengeringan yang mempengaruhi kualitas aroma dan tekstur dari produk. Pada proses pengolahan ikan asin Jambal Rori ini proses fermentasi sangat berpengaruh penting terhadap keberhasilan produksi, karena pada proses fermentasi akan menghasilkan cita rasa dan aroma khas yang keluar dari ikan tersebut (Rahayu et al., 1992). Mengemukakan pula bahwa pada pembuatan ikan asin Jambal Roti melibatkan proses fermentasi. Proses fermentasi yang dilakukan pada ikan mengakibatkan terjadinya reaksi proteolitik yang merupakan proses penguraian secara biologis terhadap senyawa-senyawa yang lebih sederhana dan terkontrol. Selama proses fermentasi, terdapat unsur-unsur ikan yang terhidrolis menjadi unsur lain seperti protein menjadi asam amino pada peptide, kemudian asam amino menjadi komponen lain yang membentuk citra. Proses pembuatan ikan asin Jambal Roti, sebagai berikut :

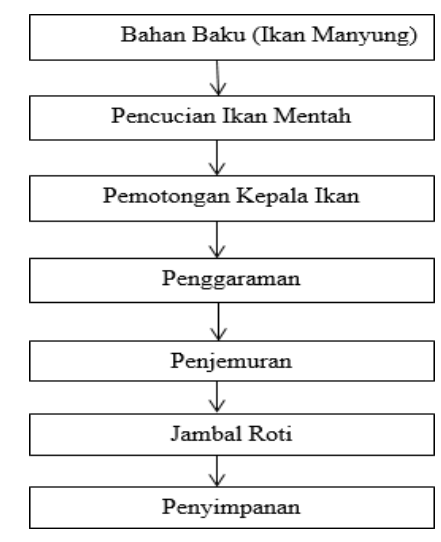

\section{Manajemen Strategi}

Strategi merupakan rencana yang disatukan secara luas, berjangka dan berintegrasi. Menghubungkan suatu industri, Dengan tantangan yang dirancang untuk memastikan tujuan utama agar dicapai pelaksanaan yang tepat (Sedarmayanti, 2014).

\section{Strategi}

Strategi adalah tujuan jangka panjang dari suatu perusahaan,serta pendayagunaan dan alokasi semua sumber daya yang penting untuk mencapai tujuan tersebut. Pemahaman yang baik mengenai konsep strategi yang disusun (Rangkuti, 2015). Konsep- konsep tersebut adalah sebagai berikut:

a.distinctive competence: tindakan perusahaan agar lebih baik dibandingkan dengan pesaingnya.

b. competitiv advantage: kegiatan perusahaan untuk lebih unggul daripada pesaingnya.

\section{Analisis SWOT}

Analisis SWOT adalah alat analisis untuk merumuskan strategi perusahaan dengan mengidentifikasi faktor-faktor. Didalam Analisis ini terdapat analisis faktor kekuatan (Strengths) dan peluang (Opportunities). Namun secara kebersamaan dapat meminimalkan kelemahan (Weakneses) dan ancaman (Treats).

\section{Analisis Lingkungan Internal}

Analisis lingkungan internal terdiri dari faktor Strengths (kekuatan) dan Weakness (kelemahan). Strengths (kekuatan) adalah kekuatan yang dimiliki dalam organisasi. Kekuatan yang dianalisis yaitu 
faktor yang terdapat didalam, sedangkan weakness (kelemahan) merupakan kelemahan yang ada di organisasi,. Kelemahan dapat dianalisis melalui faktor-faktor yang etrdaat didalam organisasi.

\section{Analisis Lingkungan Eksternal}

Analisis lingkungan eksternal terdiri dari faktor Opportunities (peluang) dan Treaths (ancaman). Opportunities (peluang) merupakan kesempatan untuk mengembangkan organisasi mnejadi lebih berkembang baik kondisi saat ini atau untuk kondisi masa datang. Kondisi yang terjadi merupakan peluang dari luar organisasi, proyek atau konsep usaha itu sendiri.misalnya competitor, kebijakan pemerintah, kondisi lingkungan sekitar, sedangkan threats (ancaman) merupakan kondisi yang mengancam dari luar. Ancaman ini dapat mengganggu organisasi, proyek atau konsep bisnis.

\section{Matriks SWOT}

Alat menyusun faktor-faktor strategis perusahaan adalah matriks SWOT. Matrik ini dapat membantu menganalisis bagaimana kekuatan dan kelemahan dapat disesuaikan dengan peluang dan ancaman eksternalnya, matriks ini dapat menghasilkan empat set kemungkinan alternatife strategi. Setelah mengumpulkan semua informasi yang berpengaruh terhadap keberlangsungan perusahaan, tahap selanjutnya adalah memanfaatkan semua informasi tersebut dalam model-model kuantitatif perumusan strategi, dalam hal ini digunakan SWOT (Rangkuti, 2015).

\section{Penelitian Terdahulu}

Howara (2013), judul penelitian Strategi Pengembangan Pengolahan Hasil Perikanan di Kabupaten Donggala, Studi Kasus di Kabupaten Donggala, Sulawesi Tengah. Program studi Agribisnis, Fakultas Pertanian Universitas Tadulako. Nurminingsih dan Shobar Wiganda (2014), Strategi Pengembangan Usaha Pengolahan Ikan. Studi Pengolahan Abon Ikan di KUB Hurip Mandiri di Kecamatan Pelabuanratu, Kabupaten Sukabumi.

\section{Posisi Penelitian Penulis}

Setelah mengetahui beberapa penelitian terdahulu yang membahas pengembangan usaha, penelitian ini memiliki kesamaan yaitu strategi pengembangan dengan menggunakan analisis SWOT, akan tetapi waktu, tempat, dan responden yang dipilih berbeda. Untuk penelitian ini akan membahas Strategi Pengembangan Usaha Pengolahan Ikan Asin Jambal Roti di Desa Pabean Udik Kecamatan Indramayu.

\section{Kerangka Pemikiran}

Strategi pengembangan usaha pengolahan memiliki aspek pasar yang luas karena permintaan produk olahan perikanan yang mempunyai nilai ekonomis. Pemanfaatan hasil perikanan dan teknologi modern mampu menciptakan produk yang berkualitas, kuantitas dan kontinuitas semakin baik sehingga harga menjadi tinggi. Analisis SWOT sebagai instrumen atau alat yang dapat menentukan pengembangan suatu usaha. Empat macam strategi tersebut adalah:

a) Strategi SO (Strenght Opportunity), digunakan untuk menangkap dan memanfaatkan peluang yang ada dengan memaksimalkan kekuatan internal.

b) Strategi WO (Weakness Opportunity), bertujuan untuk memperbaiki kelemahan internal dengan memanfaatkan peluang.

c) Strategi ST (Strenght Threat), bertjuan untuk mengurangi atau meminimalisiri ancaman dengan memanfaatkan kekuatan internal.

d) Strategi WT (Weakness Threat), digunaakan untuk memperbaiki kelemahan yang ada untuk meminimalisir ancaman. 


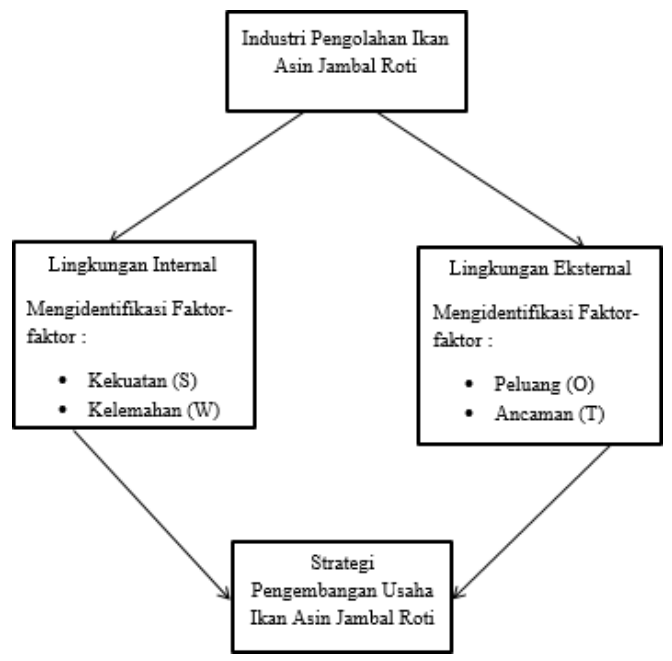

\section{METODOLOGI PENELITIAN}

\section{Objek Penelitian}

Objek penelitian ini adalah Bapak Sunarto selaku yang menjalankan usaha pengolahan ikan asin Jambal Roti Sumber Berkah di Desa Pabean Udik Kecamatan Indramayu Kabupaten Indramayu.

\section{Metode Penelitian dan Desain Penelitian}

\section{Metode Penelitian}

Metode penelitian yang digunakan dalam penelitian ini menggunakan metode survei yaitu penelitian yang mengumpulkan informasi untuk menggambarkan berbagai aspek dari populasi (Fraenkel dan Wallen, 1990). Tujuan penelitian survei adalah untuk mengetahui karakteristik populasi. Penelitian survei digunakan untuk mengumpulkan informasi berbentuk opini dari sejumlah besar orang terhadap topik atau isu tertentu.

Selain metode survei digunakan juga metode analisis SWOT. Sedarmayanti (2014), menyatakan bahwa analisis SWOT sebagai kerangka pilihan pada periode waktu yang panjang. Karena kesederhanaan dan kemampuan untuk menggambarkan esensi dan formulasi strategi yang baik. Dianalisis lebih lanjut secara kualitatif dan kuantitatif.

\section{Desain Penelitian}

Desain penelitian yang digunakan dalam penelitian ini dengan menggunakan survei deskriptif. Menurut Singarimbun dan Effendi (1985), bahwa suvei deskriptif dimaksudkan untuk pengukuran yang cermat terhadap fenomena tertentu, pengembangan konsep serta penghimpunan fakta.

\section{Definisi dan Operasionalisasi Variabel}

Untuk kelancaran pengukuran dan pengumpulan data yang diperlukan maka dalam penelitian ini diberikan batasan-batasan mengenai variabel-variabel yang berhubungan dengan usaha pengembangan ikan asin Jambal Roti sebagai berikut:

1.Faktor internal yaitu faktor strategi yang berasal dari dalam usaha pengolahan ikan asin Jambal Roti.

2.Faktor Eksternal yaitu faktor yang berasal dari luar usaha pengolahan ikan asin Jambal Roti.

3. Strategi adalah pemilihan alternatif berupa SO, ST, WO, dan WT yang akan dirumuskan pada matrik SWOT.

4. Matriks IFAS (Internal Factor Analysis System) adalah suatu analisis yang menilai faktor internal 
(kekuatan dan kelemahan) yang ada untuk mencapai tujuan perusahaan.

5.Matriks EFAS (Eksternal Factor Analysis System) adalah suatu analisis yang menilai faktor eksternal (peluang dan ancaman) yang ada untuk mencapai tujuan perusahaan.

6. Matriks IE (Internal Eksternal) adalah suatu matriks strategi yang memposisikan berbagai divisi suatu organisasi dalam tampilan sembilan sel yang dapat merumuskan strategi.

7. Matriks QSPM adalah suatu alat analisis tahap keputusan terakhir dalam strategi untuk menentukan strategi yang diprioritaskan dalam perusahaan.

\section{Jenis dan Sumber Daya}

Jenis yang diperoleh dalam penelitin ini yaitu data primer dan data sekunder, sebagai berikut:

a.Data primer

Data primer adalah data yang diperoleh langsung dari responden di lokasi penelitian yaitu usaha pengolahan ikan asin Jambal Roti Bapak Sunarto, dengan teknik pengumpulan data dan dilakukan melalui wawancara dengan menggunakan kuesioner yang telah disiapkan.

b.Data Sekunder

Data sekunder diperoleh dari berbagai sumber pustaka atau dokumen dari Instansi Pemerintah Indramayu, KPL Mina Sumitra, dan Badan Pusat Statistik Kabupaten Indramayu yang berupa:

1.Data Produksi Perikanan Tangkap Ikan Manyung 2.Data keadaan umum daerah penelitian dan data-data yang berkaitan dengan penelitian.

\section{Populasi dan Sampel \\ Populasi}

Populasi dalam penelitian ini adalah pengusaha yang mengelola ikan menjadi ikan asin Jambal Roti di Desa Pabean Udik Kecamatan Indramayu Tahun 2018, dengan populasi berjumlah 4 pengusaha pengelola ikan asin Jambal Roti. (Dinas Perikanan dan Kelautan Kabupaten Indramayu, 2017).

\section{Sampel}

Teknik pengambilan sampel secara purposive, dengan berdasarkan hasil observasi lapangan yaitu terdapat satu pengusaha yang mengelola ikan Manyung menjadi ikan asin Jambal Roti di Desa Pabean Udik, yaitu bapak Sunarto. Alasan penulis mengambil sampel di UD.

\section{HASIL DAN PEMBAHASAN}

Pengusaha pengolahan ikan asin Jambal Roti terdapat 4 orang yaitu Bapak Sunarto, Bapak Sakim, Bapak H. Iman dan Bapak Jamal di Desa Pabean Udik Kecamatan Indramayu Kabupaten Indramayu. Dari keempat responden tersebut, dua diantaranya sudah tidak aktif dalam pengolahan ikan asin Jambal Roti sejak tahun 2017, yaitu Bapak H. Desa Pabean Udik merupakan salah satu desa menjadi sentra pengolahan ikan Manyung menjadi ikan asin Jambal Roti, yang berlokasi di jalan Tanggul Praja Gumiwang Desa Pabean Udik Kecamatan Indramayu Kabupaten Indramayu. Lokasi ini dipilih karena selain mempelopori usaha masyarakat pada sub sektor perikanan, juga dekat dengan TPI (Tempat Pelelangan Ikan) Karangsong, sehingga memudahkan untuk mendapatkan bahan baku produksi, berupa ikan Manyung. Lokasi produksi yang berdekatan dengan TPI juga memberikan manfaat terhadap penekanan biaya transportasi dalam pembelian bahan baku.

Proses pengolahan ikan asin Jambal Roti dilakukan secara sederhana karena menggunakan peralatan yang sederhana dan masih bersifat manual, dan kemasan ikan asin Jambal Roti masih sederhana tidak menarik. Proses pengolahan ikan asin Jambal Roti relatif lebih singkat dengan tahapan proses pengolahan sebagai berikut :

Proses pengolahan terdapat lima tahapan yaitu, proses pemotongan badan ikan Manyung, penggaraman, pembelahan badan ikan Manyung, Pengeringan atau penjemuran, penyimpanan dan pengemasan. (Lampiran 7 : Hal 71).

1. Pemotongan kepala ikan Manyung, pemotongan dilakukan dari mulut ikan sampai katup insang, kemudian dibuang isi perutnya dan dicuci sampai bersih. Kepala ikan manyung dijual kepada 
pengepul atau pedagang pindang gombyang seharga Rp. 15.000,00/Kg.

2. Proses selanjutnya pengasinan ini bertujuan untuk penggawetan lami, dan membuat ikan tersebut berasa asin tentunya. Pada proses pengasinan berikut ini yang dibutuhkan adalah Garam $100 \mathrm{~kg}$ dengan bahan baku $500 \mathrm{~kg}$. selanjutnya untuk proses perendaman dilakukan 1-2 hari tergantung keinginan seberapa tingkat keasinan ikan tersebut.

3. Kemudian badan ikan Manyung dibelah memanjang sehingga ikan terbelah dua. Dan bagian ikan tebal pada bagian punggug ikan bisa dibelah lagi. Lalu ikan yang terbelah dicuci sampai bersih.

4. Proses penjemuran merupakan tahapan yang sangat penting, jika proses penjemuran gagal maka ikan yang telah diasinkan tidak dapat kering secara maksimal dan hasilnya akan jelek. Keringkann satu persatu jangan ditumpuk, berilah jarak agar agar sekeliling daging ikan dapat terkena sinar matahari dengan baik dan rata. Sesekali ikan yang dijemur haruslah dibalik untuk mendapatkan kering yang merata disemu sisinya.

5. Kemudian ikan asin Jambal Roti yang sudah kering, disimpan dan dikemas.

Pemasaran suatu usaha dapat dilihat dari bauran pemasaran terdiri dari produk, harga, tempat, dan

promosi yang didalamnya akan menentukan tingkat keberhasilan pemasaran.

a. Produk (Product)

Produk utama yang dihasilkan adalah ikan asin Jambal Roti, dalam hal ini produk ikan asin Jambal Roti menggunakan bahan alami tanpa adanya bahan pengawet dan mengutamakan kualitasnya. Pemasaran ikan asin Jambal Roti terdapat di wilayah Pengandaran, Garut, Tasikmalaya, Majalengka, Sumedang, dan Cirebon. Ikan asin Jambal Roti memiliki ukuran $1 \mathrm{~kg}$ perbungkus, dalam membeli produk ikan asin Jambal Roti konsumen bisa langsung datang ketempat pembuatannya. Satu kali produksi dengan bahan baku 2 ton menghasilkan $700 \mathrm{~kg}$ ikan asin Jambal Roti.

b. Harga (Price).

Harga merupakan salah satu faktor yang sering dipertimbangkan oleh konsumen sebelum membeli suatu produk. Harga $1 \mathrm{~kg}$ ikan asin Jambal Roti dijual seharga Rp. 80.000,00/kg ikan asin jambal ukuran standar, harga Rp. 100.000,00/kg ikan asin jambal roti super.

c. Tempat (Place).

Tempat pengolahannya sangat strategis karena dekat dengan jalan, untuk membeli ikan asin Jambal Roti konsumen dapat langsung ke lokasi pengolahan ikan asin Jambal Roti yaitu di jalan Tanggul Praja Gumiwang Desa Pabean Udik Kecamatan Indramayu.

d. Promosi (Promotion).

Promosi juga bisa sebagai komunikasi pemasaran yang diharapkan mampu meningkatkan penjualan produk yaitu seputar ikan asin Jambal Roti. Menjalankan strategi yang efektif dalam mempromosikan produk yang dijual dapat memberikan dampak yang luar biasa. Cara promosi produk yang pertama adalah dengan cara menjaga kualiatas daging ikan asin, selain itu bisa memanfaatkan media sosial seperti facebook, instagram dan media sosial lainnya untuk mempromosikan yang ingin dijual.

\section{Keadaan External Lingkungan Usaha Ikan Asin Jambal}

Lokasi usaha di Desa Pabean Udik merupakan salah satu desa menjadi sentra pengolahan ikan mayung menjadi ikan asin Jambal Roti, yang berlokasi di jalan Tanggul Praja Gumiwang Desa Pabean Udik Kecamatan Indramayu Kabupaten Indramayu. Lokasi ini dipilih karena selain mempelopori usaha masyarakat pada sub sektor perikanan, juga dekat dengan TPI (Tempat Pelelangan Ikan) Karangsong, sehingga memudahkan untuk mendapatkan bahan baku produksi, berupa ikan manyung. Lokasi produksi yang berdekatan dengan TPI juga memberikan manfaat terhadap penekanan biaya transportasi dalam pembelian bahan baku.

\section{Analisis Faktor Internal}

Faktor internal usaha ikan asin Jambal Roti di Desa Pabean Udik Kabupaten Indramayu terbagi atas faktor kekuatan dan faktor kelemahan. Kekuatan (strength) dalam usaha ikan asin Jambal Roti ini adalah sebagai berikut : 


\section{Kekuatan (Strength)}

Kekuatan adalah kemampuan perusahaan untuk usaha yang ikan asin Jambal Roti di Desa Pabean Udik, Adapun faktor kekuatan (Strenght) dalam usaha pengolahan ikan asin Jambal Roti ini adalah sebagai berikut :

1. Keuletan pemilik

2. Sumber daya manusia yang berpengalaman

3. Produk berkualitas

4. Proses pengolahan sederhana

5. Lokasi usaha yang strategis

6. Memiliki izin usaha dagang

2. Kelemahan (Weakness)

Adapun faktor kelemahan (weakness) dalam usaha pengolahan ikan asin Jambal Roti di Desa Pabean Udik ini adalah sebagai berikut :

1. Keterbatasan modal

2. Kurangnya promosi produk

3. Teknologi masih sederhana

4. Pemasaran masih dilakukan secara konvesional

5. Pengadministrasian masih sederhana

\section{Analisis Faktor Ekternal}

1. Peluang (Opportunity)

Peluang adalah kesempatan yang dimiliki perusahaan untuk mencapai tujuan. Adapun faktor

Peluang (Opportunity) pada usaha ikan asin Jambal Roti di Desa Pabean Udik ini antara lain :

a. Dukungan dari pemerintah

b. Adanya perkembangan teknologi produksi

c. Jangkauan pasar masih terbuka luas

d. Permintaan produk tinggi

e. Produsen ikan asin Jambal Roti masih sedikit

2. Ancaman (Treaths)

Adapun ancaman (Treaths) dalam usaha pengolahan ikan asin Jambal Roti di Desa Pabean Udik ini adalah sebagai berikut :

a. Duplikasi produk yang sama oleh produsen lain

b. Ketersediaan bahan baku

c. Limbah buang proses produksi mencemari lingkungan

d. Harga bahan baku yang mahal

\section{Analisis Matriks SWOT}

Berdasarkan faktor SWOT dalam menganalisis lingkungan internal dan ekksternal, maka dilakukan perpaduan antara elemen kekuatan, kelemahan, peluang dan ancaman dengan Matrik IFAS dan EFAS, Matrik Internal Eksternal (IE) dan Matrik SWOT. Analisis ini bertujuan untuk menentukan strategi alternatif yang terpilih. Menggambarkan secara jelas mengenai kekuatan dan kelemahan internal dengan menyelaraskan peluang dan ancaman eksternal. Beberapa strategi alternatif sebagai bahan pertimbangan dalam pengembangan usaha pengolahan ikan asin Jambal Roti di Desa Pabean Udik. Analisis matrik SWOT tersebut menghasilkan menghasilkan 4 (empat) komponen strategi yaitu (1) Strategi S-O (Strength-Opportunities); (2) Strategi W-O (Weakness-Opportunities); (3) Strategi S-T (StrenghtThrests); dan (4) Strategi W-T (Weakness-Threats). 


\section{Matriks IFAS dan EFAS}

Berdasarkan analisis lingkungan internal dan eksternal, dilakukan perhitungan analisis IFAS (Internal strategic Factor Analysis Summary) dan EFAS (Eksternal strategic Factor Analysis Summary). Penentuan bobot faktor lingkungan internal dapat dilihat pada Lampiran 3. Kemudian akumulasi penentuan bobot dimasukan ke dalam matrik IFAS untuk menentukan skor IFAS yang dapat dilihat pada Tabel 18. Hasil yang diperoleh dari Matrik IFAS (Tabel 18) nilai indeks kumulatif untuk elemen kekuatan sebesar 1,292 dan elemen kelemahan sebesar 1,297. Hal tersebut menunjukan bahwa responden Ikan Asin Jambal Roti di Desa Pabean Udik memberikan respon tinggi terhadap faktor kelemahan dan memberikan respon rendah terhadap faktor kekuatan. Total skor IFAS (Internal strategic Factor Analysis Summary) sebesar 2,590.

Setelah skor IFAS sudah ditemukan, selanjutnya adalah menghitung bobot faktor lingkungan eksternal untuk dapat menentukan skor EFAS (Eksternal strategic Factor Analysis Summary). Hasil yang diperoleh dari matrik EFAS, nilai indeks kumulatif skor peluang sebesar 1,562, sedangkan skor untuk elemen ancaman sebesar 1,556. Hal ini menunjukan responden pengusaha Ikan Asin Jambal Roti di Desa Pabean Udik memberikan respon yang tinggi terhadap faktor peluang dan respon yang rendah terhadap faktor ancaman. Total skor EFAS (Eksternal strategic Factor Analysis Summary) sebesar 3,117.

\section{Analisis Matriks Internal dan Eksternal (IE)}

Strategi dapat diterapkan setelah diketahui posisi usaha Ikan Asin Jambal Roti di Desa Pabean Udik dalam Matrik Internal Eksternal (IE). Tujuannya untuk memperoleh strategi dalam pengembangan usaha Ikan Asin Jambal, melihat posisi dan arah perkembangan selanjutnya.

Total skor yang diperoleh dari matrik IFAS sebesar 2,590 dan total skor yang diperoleh dari matrik EFAS sebesar 3,117. Hal ini menunjukkan titik koordinat terletak pada kuadran II yaitu Growth (konsentrasi melalui integrasi horizontal) yang memiliki arti bahwa komponen strategi yang dapat diterapkan yaitu strategi S-O (Strenght-Opportunities), memaksimalkan kekuatan untuk memanfaatkan peluang yang ada. Adapun strategi yang dapat digunakan oleh pengusaha Ikan Asin Jambal Roti di Desa Pabean Udik adalah sebagai berikut :

1. Meningkatkan jumlah produksi dengan cara produsen mempunyai persediaan bahan baku untuk mengantisipasi permintaan produk yang tinggi dan dapat menjangkau pasar yang lebih luas.

2. Meningkatkan kemauan dan Memanfaatkan dukungan pemerintah daerah setempat agar usaha ikan asin jambal roti mendapatkan dukungan dari segi mempermudah perizinan dan jangkauan akses pasar yang luas dan pendanaan dengan bunga yang ringan.

\section{Pengabilan Keputusan Dengan QSPM (Quantitave Strategy Planning Matriks)}

Berdasarkan strategi alternatif yang dihasilkan dari analisis SWOT, maka pemilihan strategi terbaik menurut prioritas dengan menggunakan alat bantu analisis QSPM (Quantitative Strategic Planning Matrix). Analisis ini digunakan untuk mengevaluasi strategi alternatif secara objektif. Berdasarkan faktorfaktor strategi untuk sukses internal dan eksternal sebelumnya, pengolahan SWOT menghasilkan 2 (dua) strategi.

Tahap selanjutnya yaitu untuk mengambil keputusan menentukan prioritas strategi yang paling tepat untuk dilaksanakan terlebih dahulu. Maka dilakukan analisis QSPM (Quantitative Strategic Planning Matrix), untuk menentukan jenis strategi usaha Ikan Asin Jambal Roti dilakukan melalui penilaian terhadap strategi yang diusulkan kepada responden. Analisis tersebut menghasilkan urutan prioritas strategi yang harus dilakukan oleh pelaku usaha Ikan Asin Jambal Roti di Desa Pabean Udik yang dapat dilihat pada Tabel 3 . 
Tabel 3. Urutan prioritas strategi yang harus dilakukan oleh pelaku usaha Ikan Asin Jambal Roti di Desa Pabean Udik

No

1.

Meningkatkan jumlah produksi dengan cara produsen mempunyai persediaan bahan baku untuk mengantisipasi permintaan produk yang

2.
Strategi

TAS
Meningkatkan kemauan dan Memanfaatkan dukungan pemerintah daerah setempat agar usaha ikan asin jambal roti mendapatkan dukungan dari segi mempermudah perizinan dan jangkauan akses pasar yang luas dan pendanaan dengan bunga yang ringan tinggi dan dapat menjangkau pasar yang lebih luas.

Keterangan : TAS (Total Attractiveness Scores)

\section{SIMPULAN DAN SARAN}

\section{Simpulan}

Berdasarkan hasil pembahasan mengenai Strategi Pengembangan Usaha Ikan Asin Jambal Roti di Desa Pabean Udik Kecamatan Indramayu Kabupaten Indramayu Tahun 2018, dapat disimpulkan sebagai berikut :

1. Faktor internal yang meliputi kekuatan dan kelemahan yang dimiliki Usaha Pengolahan Ikan Asin Jambal Roti adalah faktor Strengths (Kekuatan) meliputi : Keuletan pemilik. Sumber daya manusia yang berpengalaman. Produk berkualitas. Proses pengolahan tidak rumit. Lokasi usaha yang strategis. Memiliki izin usaha dagang. Dan faktot Weakness (Kelemahan) meliputi: Keterbatasan modal. Kurangnya promosi produk. Teknologi masaih sederhana. Pemasaran masih dilakukan secara konvesional. Pengadministrasian masih sederhana.

2. Faktor eksternal yang meliputi peluang dan ancaman yang dimiliki Usaha Pengembangan Ikan Asin Jambal Roti adalah faktor Opportunities (Peluang) meliputi : Dukungan dari pemerintah. Adanya perkembangan teknolgi produsi. Jangkauan masih terbuka luas. Permintaan produk tinggi. Produksi ikan asin Jambal Roti masih sedikit. Dan faktor Threats (Ancaman) meliputi : Duplikasi produk oleh usaha lain. Ketersediaan bahan baku. Limbah buang proses produksi mencemari lingkunga. Harga bahan baku yang mahal.

3. Alternative strategi pengembangan usaha pengolahan ikan asin jambal roti yang di peroleh adalah S-O yaitu kekuatan (Strenght) dan peluang (Oportuities) dimana perusahaan memiliki strategi untuk memaksimalkan kekuatan untuk memanfaatkan peluang yang ada. (1) Meningkatkan kemauan dan Memanfaatkan dukungan pemerintah daerah setempat agar usaha ikan asin jambal roti mendapatkan dukungan dari segi mempermudah perizinan dan jangkauan akses pasar yang luas dan pendanaan dengan bunga yang ringan. (2) Meningkatkan jumlah produksi dengan cara produsen mempunyai persediaan bahan baku untuk mengantisipasi permintaan produk yang tinggi dan dapat menjangkau pasar yang lebih luas produksi dengan cara produsen mempunyai persediaan bahan baku untuk mengantisipasi permintaan produk yang tinggi dan dapat menjangkau pasar yang lebih luas. 
Saran

Berdasarkan hasil penelitian dan pembahasan faktor internal dan eksternal yang mendukung usaha ikan asin Jambal Roti di Desa Pabean Udik Kecamatan Indramayu Kabupaten Indramayu, maka diajukan beberapa saran sebagai berikut :

1. Perusahaan harus lebih baik lagi untuk menghasilkan produk yang berkualitas dengan cara menggunkann teknologi yang modern dan bahan baku yang berkulitas yaitu dilihat dari ikan yang segar.

2. Pengusaha harus menindaklanjuti bagaimana caranya agar limbah tidak dibuang ke sungai agar lingkungan disekitar tidak tercemar dengan cara membuat penampungan pembuangan limbah produksi.

3. Dalam pemasaran ikan asin Jambal Roti harus terjalin baik antara pemilik dengan karyawan dengan cara menerapkan kegiatan yang bisa diikuti oleh karyawan, maka dengan itu hubungan pengusaha dengan karyawan dapat bekerjasama dan saling menguntungkan.

\section{Ucapan Terimakasih}

Ucapan Terimaksih saya ucapkan kepada Fakultas Pertanian dan LPPM UNWIR yang telah membantu dalam penelitian ini sehingga penelitian dapat dijalankan.

\section{DAFTAR PUSTAKA}

Adawyah. 2007. Pengolahan dan Pengawetan Ikan. Jakarta: Bumi Aksara.

Badan Pusat Statistik Kabupaten Indramayu 2017. Indramayu Dalam Angka. Indramayu.

Badan Pusat Statistik Kabupaten Indramayu 2017. Indramayu Dalam Angka. Indramayu

Badan Pusat Statistik Kabupaten Indramayu 2018. Indramayu Dalam Angka. Indramayu

Burhanuddin, S., A.Djamali, S. Martosewojo dan M. Hutomo. 1987. Sumber Daya Ikan Mnyung di Indonesia. Lembaga Oseanologi Nasional - LIPI. Jakarta.

David FR. 2006. Strategi Manajemen. Banyuwangi. Jakarta.

Ditjen Perikanan Tangkap. 2017. Produksi Perikanan Tangkap. Jakarta.

Djuhanda, T. 1981. Dunia Ikan. Bandung: Armico. 191 hal. 